\title{
Epigenetic regulation of CD1d-mediated antigen presentation in B cell lymphoma
}

\author{
Irina Tiper ${ }^{*}$, Tonya J Webb \\ From Society for Immunotherapy of Cancer 29th Annual Meeting \\ National Harbor, MD, USA. 6-9 November 2014
}

Tumors frequently alter antigen processing and presentation by major histocompatibility complex (MHC) proteins in order to evade recognition by the immune system. CD1d, a non-polymorphic MHC class I-like molecule, presents lipid antigens to Natural killer T (NKT) cells, which have potent anti-tumor effector functions. NKT cells are able to directly lyse malignant cells and induce anti-tumor responses by modulating other immune cells. Many hematologic malignancies express CD1d and the co-stimulatory proteins needed to induce anti-tumor responses by NKT cells, yet most tumors are poorly immunogenic. Here we sought to test the hypothesis that B cell lymphomas use epigenetic mechanisms to dysregulate CD1d-mediated antigen processing and presentation leading to a functional impairment in the ability of NKT cells to recognize tumors. To assess the functional outcomes of epigenetic modulation, murine and human B cell lymphomas were pretreated with HDAC inhibitors and then we assessed their ability to process and present antigen. Pretreatment with Trichostatin A (TSA) resulted in a dose-dependent increase in CD1d-mediated NKT cell activation by lymphoma cells without altering CD1d or co-stimulatory molecule cell surface expression. Similarly, pretreatment with TSA enhanced MHC class II mediated antigen presentation to CD4+ T cells. In contrast, treatment with the more selective HDACi, MC1568, resulted in an increase in CD1d-mediated NKT cell activation, but did not enhance antigen presentation by HLA-DR4. These data indicate that HDACi differentially modulate CD1d and MHC class II-mediated antigen presentation and suggests a role for multiple HDACs in regulating antigen processing and presentation. Overall, our studies demonstrate the efficacy of HDACi in restoring NKT cell mediated anti-tumor responses and may provide the basis for an NKT cellbased immunotherapeutic strategy that not only enhances

University of Maryland School of Medicine, Baltimore, MD, USA the immune response, but also increases the immunogenicity of the tumor itself.

Published: 6 November 2014

doi:10.1186/2051-1426-2-S3-P177

Cite this article as: Tiper and Webb: Epigenetic regulation of CD1dmediated antigen presentation in B cell lymphoma. Journal for ImmunoTherapy of Cancer 2014 2(Suppl 3):P177.

Submit your next manuscript to BioMed Central and take full advantage of:

- Convenient online submission

- Thorough peer review

- No space constraints or color figure charges

- Immediate publication on acceptance

- Inclusion in PubMed, CAS, Scopus and Google Scholar

- Research which is freely available for redistribution 